\title{
INFLUENCE OF TEA TREE ESSENTIAL OIL ON THE SYNTHESIS OF MYCOTOXINS: OCHRATOXIN A
}

\author{
Nikola Puvača ${ }^{1 *}$, Vojislava Bursić ${ }^{2}$, Aleksandra Petrović ${ }^{2}$, Radivoj Prodanović1, \\ Mansour Mohammed Kharud ${ }^{1}$, Dejan Obućinski ${ }^{1}$, Gorica Vuković ${ }^{3}$, Miloš Marić \\ ${ }^{1}$ Department of Engineering Management in Biotechnology, \\ Faculty of Economics and Engineering Management, University Business Academy, \\ Cvećarska 2, 21000 Novi Sad, Serbia \\ ${ }^{2}$ Department for Plant and Environmental Protection, Faculty of Agriculture, \\ University of Novi Sad, Trg Dositeja Obradovića 8, 21000 Novi Sad, Serbia \\ ${ }^{3}$ Department of Food Safety, Institute of Public Health of Belgrade, \\ Blvd. Despota Stefana 54a, 11000 Beograd, Serbia \\ nikola.puvaca@gmail.com
}

\begin{abstract}
A b s t r a c t: The aim of the study was to investigate the influence of tea tree essential oil (Melaleuca alternifolia) on ochratoxin A synthesis by fungi. Commercially available tea tree essential oil was perched from Infinity Feed Company from Novi Sad, Serbia. Qualitative analyses of tea tree essential oil were performed by GC-MS. The toxigenic activity of the essential oil $(7.5 ; 15.0$ and $30.0 \mu \mathrm{g} / \mathrm{ml})$ was evaluated by inhibiting the production of ochratoxin A by Aspergillus niger. The quantification of the toxin was performed by HPLC. The production of ochratoxin A was dependent on the incubation temperature, 20 and $30^{\circ} \mathrm{C}$ in the presence of the essential oil. Obtained values from $20^{\circ} \mathrm{C}$ showed a reduction in ochratoxin A synthesis that ranged from 53.87 to $96.22 \%$, and from 18.36 to $72.85 \%$ at $30^{\circ} \mathrm{C}$, for the A. niger, respectively. Based on the obtained results from this research, it was concluded that tea tree essential oil as a natural products could serve as potential biocontrol agent against ochratoxin A contamination in feed.
\end{abstract}

Key words: essential oil; mycotoxins; feed; safety

\section{ВЛИЈАНИЕ НА ЕСЕНЦИЈАЛНОТО МАСЛО ОД ЧАЈНО ДРВО ВРЗ СИНТЕЗАТА НА МИКОТОКСИНИ: ОХРАТОКСИН А}

А п с т р а к т: Целта на оваа студија беше да се истражи влијанието на есенцијалното масло од чајното дрво (Melaleuca alternifolia) врз синтезата на охратоксин А од габи. Комерцијално достапното масло од чајно дрво беше набавено од компанијата за добиточна храна Infinity од Нови Сад, Србија. Квалитативните анализи на есенцијалното масло од чајно дево беа изведени со GC-MS. Токсигенетската активност на есенцијалното масло $(7,5,15,0$ и $30,0 \mu \mathrm{g} / \mathrm{ml})$ беше оценета со инхибирање на производството на охратоксин А од Aspergillus niger. Квантификацијата на токсинот беше изведена со HPLC. Производството на охратоксин А беше зависно од температурата на инкубација, 20 и $30{ }^{\circ} \mathrm{C}$ во присуство на есенцијално масло. Добиените вредности од $20^{\circ} \mathrm{C}$ покажаа намалување на синтезата на охратоксинот А, која се движеше од 53,87 до $96,22 \%$, а на $30^{\circ} \mathrm{C}$ од 18,36 до $72,85 \%$, за A. niger, соодветно. Врз основа на добиените резултати од ова истражување може да се заклучи дека маслото од чајно дрво како природен продукт може да послужи како додадок во добиточната храна за биоконтрола против загадување со охратоксинот А.

Клучни зборови: есенцијално масло; микотоксини; добиточна храна; безбедност

\section{INTRODUCTION}

Mycotoxins, the secondary metabolites of fungi, are a worldwide concern. At aerobic conditions, fungal growth in various feed raw materials is inevitable. There are about 200 species of fungi that produce mycotoxins. Majority of the fungi that form mycotoxin belong to three genuses: Aspergillus, Penicillium and Fusarium [2]. 
Mycotoxins contamination and the development of fungi in feed present as well a major public health problem. An alternative method for reducing feed contamination by ochratoxin A involves the use of essential oils [10].

Essential oils are secondary metabolites obtained from plants and are constituted mainly of mono- and sesquiterpenes and phenylpropanoids, which are compounds that are responsible for the organoleptic properties of the oils [6].

The essential oil from tea tree (Melaleuca alternifolia) is widely used as an active ingredient in many formulations for animal nutrition because of its antimicrobial, antioxidative and acaricidal properties [8]. Tea tree exhibits wide spectrum of antimicrobial activity. Its mode of action against the Gram-negative bacterium Escherichia coli, the Gram-positive bacterium Staphylococcus aureus, and the yeast Candida albicans has been investigated using a range of different methods. As antimicrobial, tea tree possess high inhibitory antifungal activity because of its components such as terpinen4-ol, $\alpha$-terpineol, linalool, $\alpha$-pinene, $\beta$-pinene and $\beta$ myrcene followed by 1,8-cineole. Bioactive compounds such as $\alpha$-terpinene, $\alpha$-terpinolene and $\gamma$-terpinene show high antioxidant activity of tea tree. Also, tea tree with its components is known to possess bacteriostatic and germicidal properties and is used to cure infections of the skin and mucous membranes such as boils, abscesses and onychomycosis caused by Candida [7, 11].

According to some research, Backhousia citriodora possesses antifungal properties that might result from the action of citral, the principal component of the essential oil. During life cycle fungi metabolize and synthesize many organic compounds with numerous diabolical properties. Nowadays, significant increase of raw materials contamination by fungi has led to high losses in industrial feed production because of high share of feed deterioration and production of mycotoxins [1].

Aspergillus niger produces ochratoxin A through to its secondary metabolism. This mycotoxin has been detected in raw plant materials such as cereals, fruits and also it could be found in almost $25 \%$ of the world's agricultural commodities [9]. Consuming the contaminated feed with mycotoxins, animals can suffer nephrotoxic, cancerogenic, immunotoxic, teratogenic and genotoxic effects of ingested mycotoxins.

The making the most of the biological activities of the essential oils can present the alternative form of controlling microorganisms, in order to minimize the unfavourable influence for usage of chemical additives as preservatives in raw materials for animal nutrition $[1,7,9]$.

Having in mind the aforementioned, the aim of the study was to investigate the influence of tea tree essential oil (Melaleuca alternifolia) on ochratoxin A synthesis by fungi.

\section{MATERIALS AND METHODS}

\section{Composition of the essential oil}

Qualitative analyses were performed by gas chromatograph with mass spectrometer (GC-MS). The chromatograph was equipped with a fused silica (5\% phenyl, 95\% dimethylpolysiloxane) capillary column $(30 \mathrm{~m} \times 0.25 \mathrm{~mm}$ i.d.; $0.25 \mu \mathrm{m}$ film), employing Helim as the carrier gas at a flow rate of $1.2 \mathrm{ml} / \mathrm{min}$. The MS employed an ion capture detector operating by electron impact and an impact energy of $70 \mathrm{eV}$. The retention indices were after that calculated.

Quantitative analyses were performed using a gas chromatograph with a flame ionization detector (FID) under the following operational conditions: ZB-5MS fused-silica (5\% phenyl, 95\% dimethylpolysiloxane) capillary column $(30 \mathrm{~m} \times 0.25 \mathrm{~mm}$ id; $0.25 \mu \mathrm{m}$ film), using Helim as the carrier gas with a flow rate of $1.2 \mathrm{ml} / \mathrm{min}$. The temperature was maintained at $50{ }^{\circ} \mathrm{C}$ for 2 minutes and then was increased at the rate of $4{ }^{\circ} \mathrm{C} / \mathrm{min}$ to $200{ }^{\circ} \mathrm{C}$, followed by an increase of $15{ }^{\circ} \mathrm{C} / \mathrm{min}$ to $300{ }^{\circ} \mathrm{C}$, where the temperature was maintained for 15 minutes. The injector temperature was $250{ }^{\circ} \mathrm{C}$, and the detector temperature was $280{ }^{\circ} \mathrm{C}$. A $0.5 \mu$ l volume of tea tree essential oil in hexane was applied to the column $(\geq 98 \%)$.

\section{Activity of tea tree essential oil in ochratoxin A synthesis}

The mycotoxic effect of the essential oil was evaluated by the method previously in detailed described in research of Wang et al. [12], where the production of ochratoxin A by the A. niger fungi in culture medium was inhibited by the addition of the essential oils. To obtain the inoculum, maize fungal isolates were transferred to plates containing the Czapek agar culture medium and further on they where incubated at $30{ }^{\circ} \mathrm{C}$ for next 7 days. A suspension of the spores in sterile distilled water containing $0.5 \%$ Tween 80 was prepared. A Neubauer 
counting chamber was used to determine the final spore concentration $\left(10^{7}\right.$ spores $\left./ \mathrm{ml}\right)$.

Aliquots of the spore suspension in amount of $10 \mu \mathrm{l}$ were inoculated in the center of the plate containing Czapek agar culture medium supplemented with different concentrations of the tea tree essential oil diluted in dimethylsulfoxide. The control and three concentrations of the tea tree essential oil (7.5; 15.0 and $30.0 \mu \mathrm{g} / \mathrm{ml}$ ) were tested. The plates were incubated in a chamber in the dark at 20 and $30{ }^{\circ} \mathrm{C}$ for next 10 days.

\section{Extraction of ochratoxin A from the A. niger}

Ochratoxin A was extracted according to the method previously described by Passamani et al. [5]. Three colony plugs were removed from the internal area, the middle and the edge of each colony on the $10^{\text {th }}$ day of incubation. After removal, plugs were weighed and deposited in test tubes wrapped in aluminum foil, and $1 \mathrm{ml}$ of methanol was added to the tubes. The tubes were stirred for $5 \mathrm{~s}$ and were kept at room temperature for $60 \mathrm{~min}$. The extracts were filtered through polytetrafluoroethylene filters $(0.22 \mu \mathrm{m})$ and analyzed on a HPLC/FLD. An Agilent Zorbax Eclipse XDB-C18 $(4.6 \mathrm{~mm} \times 250$ $\mathrm{mm}, 5 \mu \mathrm{m}$ ) column connected to an Agilent Zorbax Eclipse XDB-C18 4-Pack guard column (4.6 mm $\times$ $12.5 \mathrm{~mm}, 5 \mu \mathrm{m})$ was used. The wavelengths employed were $332 \mathrm{~nm}$ for excitation and emission at $476 \mathrm{~nm}$. The quantitative determination of ochratoxin $\mathrm{A}$ in the samples was performed by external standard calibration.

The limits of detection (LD) and quantification (LQ) were estimated using the parameters obtained from the calibration curve, calculated by mathematical equation: $\mathrm{LD}=3 \mathrm{DP} / \mathrm{m}$ and $\mathrm{LQ}=10 \mathrm{DP} / \mathrm{m}$ (where SD = estimate of the standard deviation of the regression line, and $\mathrm{m}=$ slope of the calibration line).

\section{Statistical analyses}

The data obtained in the experiment firstly were tested for the normality of data spread and then analyzed by one-way ANOVA within statistical software Statistica 13 (TIBCO Software Inc, USA), to determine whether variables differed among essential oil concetrations. When the ANOVA showed statistical significance, Duncan's multiple range test was conducted and $\mathrm{p}<0.05$ indicated significant difference.

\section{RESULTS AND DISCUSSION}

The principal constituents in the tea tree essential oil (Melaleuca alternifolia) are presented in Table 1. Main bioactive substances detected in essential oil found to be terpinen-4-ol $(57.45 \%), \gamma$-terpinene $(21.69 \%)$ and $\rho$-cymene $(10.15 \%)$.

The chemical composition of tea tree oil has been well defined and consists largely of cyclic monoterpenes of which about $50 \%$ are oxygenated and about $50 \%$ are hydrocarbons. Tea tree essential oil as a main component exhibits broad spectrum antimicrobial activity which can be principally attributed to terpinen-4-ol [3], which represents main bioactive substances in this research as well.

\section{Table 1}

Composition of the tea tree essential oil (\%)

\begin{tabular}{lcc}
\hline \hline Bioactive substance & Relation index & Tea tree essential oil \\
\hline$\alpha$-pinene & 931 & 2.43 \\
$\alpha$-2-carene & 1005 & 6.21 \\
$\rho$-cymene & 1019 & 10.15 \\
$\gamma$-terpinene & 1053 & 21.69 \\
Terpinen-4-ol & 1176 & 57.45 \\
$\alpha$-terpineol & 1187 & 3.00 \\
\hline \hline
\end{tabular}

The highest decrease of ochratoxin A with statically significant $(\mathrm{p}<0.05)$ of $0.013 \mu \mathrm{g} / \mathrm{g}$ was recorded at incubation temperature of $20^{\circ} \mathrm{C}$, compared to control treatment without addition of tea tree essential oil. Statistically significant difference in production of ochratoxin A was not $(p>0.05)$ recorded between different essential oil concentrations at incubation temperature of $20^{\circ} \mathrm{C}$ (Table 2).

\section{Table 2}

Effects of the tea tree essential oil on the production of ochratoxin $A(\mu g / g)$

\begin{tabular}{ccccc}
\hline \hline $\begin{array}{c}\text { Incubation } \\
\text { temperature } \\
{ }^{\circ} \mathrm{C}\end{array}$ & \multicolumn{4}{c}{ Tea tree essential oil concentration $\mu \mathrm{g} / \mathrm{ml}$} \\
\cline { 2 - 5 } & 0.0 & 7.5 & 15.0 & 30.0 \\
\hline 20 & $0.32^{\mathrm{a}}$ & $0.051^{\mathrm{b}}$ & $0.149^{\mathrm{b}}$ & $0.013^{\mathrm{b}}$ \\
30 & $0.046^{\mathrm{a}}$ & $0.019^{\mathrm{b}}$ & $0.034^{\mathrm{a}}$ & $0.026^{\mathrm{b}}$ \\
\hline \hline
\end{tabular}

Different letter indexes in the same row are statistically significantly different $(\mathrm{p}<0.05)$. 
On the other hand, significant differences ( $\mathrm{p}<$ 0.05 ) were recorded at incubation temperature of 30 ${ }^{\circ} \mathrm{C}$. The highest decrease of ochratoxin A was noticed at the lowest concentration of tea tree essential oil $(0.019 \mu \mathrm{g} / \mathrm{g})$, followed by higher concentration of essential oil $(0.026 \mu \mathrm{g} / \mathrm{g})$, while the lowest decrease was noticed at treatment with addition of $15.0 \mu \mathrm{g} / \mathrm{ml}$ of tea tree essential $(0.034 \mu \mathrm{g} / \mathrm{g})$, without statistically significant $(\mathrm{p}>0.05)$ difference compared to control treatment $(0.046 \mu \mathrm{g} / \mathrm{g})$. The most important factors influencing the growth, sporulation and toxin production by fungi are temperature and water activity, according to Magan et al. [4]. The greatest synthesis of toxin $(7.0 \mu \mathrm{g} / \mathrm{g})$ occurred at $15{ }^{\circ} \mathrm{C}$ and $A$. niger did not produce toxin at 20 to $25^{\circ} \mathrm{C}$ [5], which is similar to the results obtained in the our study.

Addition of tea tree essential oil caused a decrease in the production of ochratoxin $\mathrm{A}$ at $20^{\circ} \mathrm{C}$ that ranged from 53.87 to $96.22 \%$ and from 18.36 to $72.85 \%$ at $30^{\circ} \mathrm{C}$ for $A$ niger, respectively (Table 3 ). Jersek et al. [3] studied the activity of the essential oils obtained from thyme (Origanum vulgare L.), peppermint (Mentha piperita L.), fennel (Foeniculum vulgare Mill.) and pine (Abies alba Mill.), where they have noted the importance of these products in reducing the concentration of ochratoxin $\mathrm{A}$ produced by Penicillium verrucosum. The same authors [3] make and observation that the combination of mono- and sesquiterpenes, inhibits the growth and toxin production by the fungi. The same bioactive compounds we have found in the samples of tea tree essential oil used in this study (Table 1).

\section{Table 3}

Reduction of ochratoxin A production with the use of tea tree essential oil (\%)

\begin{tabular}{ccccc}
\hline \hline $\begin{array}{c}\text { Incubation } \\
\text { temperature } \\
{ }^{\circ} \mathrm{C}\end{array}$ & \multicolumn{4}{c}{ Tea tree essential oil concentration } \\
$\mu \mathrm{g} / \mathrm{ml}$
\end{tabular}

Different letter indexes in the same row are statistically significantly different $(\mathrm{p}<0.05)$; Reduction of ochratoxin A was calculated relative to the control, which was considered to be $100 \%$

The same decrease of ochratoxin A at $20{ }^{\circ} \mathrm{C}$ and $30^{\circ} \mathrm{C}$, with exponential trend is graphically presented in Figure 1.

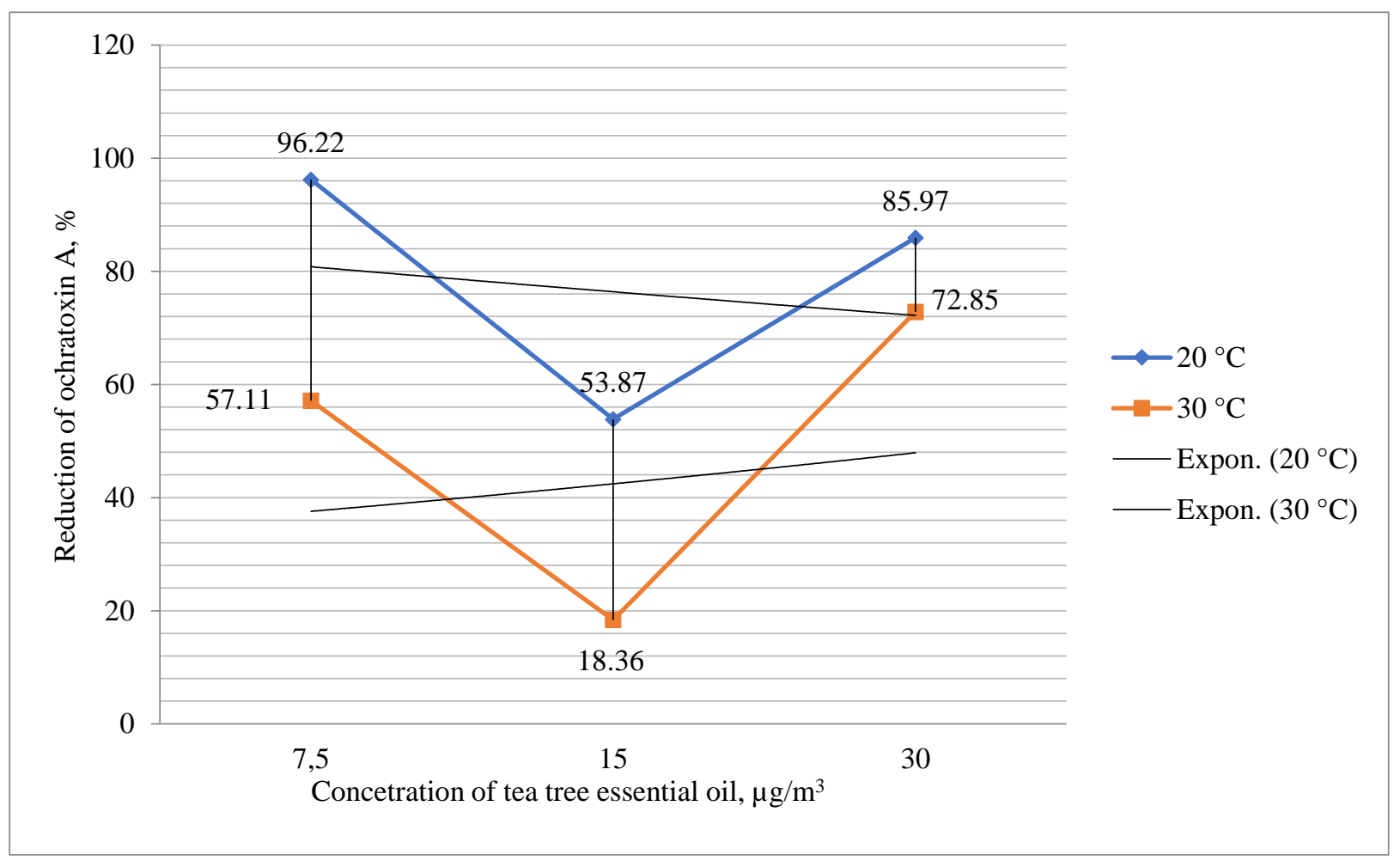

Fig. 1. Trend of ochratoxin A reduction by addition of tea tree essential oil, \% 
Based on the obtained results in this study, we suggest that essential oils be used in feed products and raw materials which are susceptible to contamination by ochratoxin A. In vivo trials are needed to confirm the effectiveness of these oils, and they should be evaluated toxicologically to certify the safety of their use for animal nutrition.

\section{CONCLUSIONS}

The essential oil from tea tree influenced the production of ochratoxin A by A. niger fungi. Essential oil addition caused an increase in ochratoxin A reduction, but further investigations in vivo dietary trials with animals are more than necessary.

Acknowledgements: This work was supported by the Ministry of Education, Science and Technological Development of the Republic of Serbia under Grants III 46012 and TR 31018.

\section{REFERENCES}

[1] Abrunhosa, L., Morales, H., Soares, C., Calado, T., Vilachã, A.S., Pereira, M., Venâncio, A.: A review of mycotoxins in food and feed products in Portugal and estimation of probable daily intakes. Crit. Rev. Food Sci. Nutr., 56 (2), 249-265 (2016). Doi: 10.1080/10408398.2012.720619.

[2] Beccari, G., Caproni, L., Tini, F., Uhlig, S., Covarelli, L.: Presence of Fusarium species and other toxigenic fungi in malting barley and multi-mycotoxin analysis by liquid chromatography-high-resolution mass spectrometry. $J$. Agric. Food Chem., 64 (21), 4390-4399 (2016).

[3] Jersek, B., Ulrih, N. P., Skrt, M., Gavaric, N., Bozin, B., Mozina, S.S.: Effects of selected essential oils on the growth and production of ochratoxin A by Penicillium verrucosum. Arch. Ind. Hyg. Toxicol., 65, 199-208 (2014).
[4] Magan, N., Medina, A., Aldred, D.: Possible climatechange effects on mycotoxin contaminant of food crops pre and postharvest. Plant Pathol., 60, 150-163 (2011).

[5] Passamani, F. R., Hernandes, T., Lopes, N. A., Bastos, S. C., Santiago, W. D., Cardoso, M. G., Batista, L. R.: Effect of temperature, water activity, and $\mathrm{pH}$ on growth and production of ochratoxin A by Aspergillus niger and Aspergillus carbonarius from Brazilian grapes. J. Food Prot., 77, 1947-1952 (2014).

[6] Popović, S., Kostadinović, Lj., Đuragić, O., Aćimović, M., Čabarkapa, I., Puvača, N., Ljubojević Pelić, D.: Influence of medicinal plants mixtures (Artemisia absinthium, Thymus vulgaris, Menthae piperitae and Thymus serpyllum) in broilers nutrition on biochemical blood status. J. Agron. Technol. Eng. Manag., 1 (1), 91-98 (2018).

[7] Puvača, N., Čabarkapa, I., Bursić, V., Petrović, A., Aćimović, M.: Antimicrobial, antioxidant and acaricidal properties of tea tree (Melaleuca alternifolia). J. Agron. Technol. Eng. Manag., 1 (1), 29-38 (2018).

[8] Puvača, N., Čabarkapa, I., Petrović, A., Bursić, V., Prodanović, R., Soleša, D., Lević, J.: Tea tree (Melaleuca alternifolia) and its essential oil: Antimicrobial, antioxidant and acaricidal effects in poultry production. Worlds Poult. Sci. J., 75 (2), 1-12 (2019) Doi:10.1017/S0043933919000229.

[9] Rao, J., Chen, B., McClements, D.J.: Improving the efficacy of essential oils as antimicrobials in foods: Mechanisms of action. Annu. Rev. Food Sci. Technol., 10 (1), 365-387 (2019).

[10] Shanakhat, H., Sorrentino, A., Raiola, A., Romano, A., Masi, P., Cavella, S.: Current methods for mycotoxins analysis and innovative strategies for their reduction in cereals: an overview. J. Sci. Food Agric., 98 (11), 4003-4013 (2018).

[11] Tomičić, Z., Čabarkapa, I., Čolović, R., Đuragić, O., Tomičić, R.: Salmonella in the feed industry: Problems and potential solutions. J. Agron. Technol. Eng. Manag., 2 (1), 130-137 (2019).

[12] Wang, H., Liu, Y., Wei, S., Yan, Z.: Comparative seasonal variation and chemical composition of essential oils from the leaves and stems of Schefflera heptaphylla using microwave-assisted and conventional hydrodistillation. Ind. Crops Prod., 36, 229-237 (2012). 
